\title{
Upgrading and Global Value Chain 4.0: The Case of Palm Oil Sector
}

\section{in Indonesia}

\author{
B. Endo Gauh Perdana \\ Universitas Gadjah Mada \\ endo.gp07@gmail.com
}

The Industrial Revolution 4.0 promotes digitalization and innovation across many sectors of industries allowing them to thrive by increasing productivity, profitability, product quality and performance. However, the utilization of digital technology especially in agricultural sector, requires effective governance in which must adhere to sustainability practices for upgrading strategies. As one of the main export commodities in Indonesia, the palm oil industry is in alert to face challenges brought by the Industrial Revolution 4.0. This research draws from the latest work of Gerrefi and Lee on Global Value Chain. In the framework of horizontal industrial cluster and vertical global value chain governance, the theory examines how governance and upgrading trajectories produces economic upgrading which correlates to social and environmental upgrading. This research, then scrutinizes the question posed by the role of technology which supports as well as accelerates the upgrading strategies. The GVC analysis of Indonesian palm oil industry will be used as a case study to understand the complexity of how actors operate in every cluster of governance. Economic upgrading is not always associated with social and environmental upgrading. Therefore, a strong linkage between actors suggests that the Industrial Revolution 4.0 is relevant and essential to enhance synergy to cater for economic, social and environmental dimensions in order to harness the potential of sustainable development.

Keywords: global value chain; governance; upgrading; palm oil; sustainable development

\section{Introduction}

The wave of the Industrial Revolution 4.0 developes in unprecedented speed across many sectors of economy. In his recent book, The Great Convergence, Baldwin (2016) notes that since the introduction of Globalization Era in 1990s, China and India GDP are on the rise while GDP of the G7 nations are declining. This happens as technological advancement allows many countries, such as China and India, to attract investors as a result of their comparative advantages in low wages with minimal hindrances on know-how transfer.
While definitions for the Industrial Revolution 4.0 are varied, a clear essence of this wave is the marriage of physical, digital and biological spheres (Schwab, 2015).

New technological development in the forms of robotics, artificial intelligence (AI), and Internet of Things (IoT) are the backbone of this latest industrial shifts. Baldwin (2016) has classified two aspect of changes of Information, Communication and Technology (ICT). First, data processing speed is greatly enhanced and a number of tasks is reduced as a consequence from Industrial Revolution 4.0 
and AI (Baldwin, 2016). Therefore, jobs will be disrupted because some jobs will eventually redundant and replaced by machines. Second, physical distances are no longer considered challenges as the Internet has cut the cost of communication.

The economy model is then transformed into digital economy with the rise of internet users as an important element of Industrial Revolution 4.0, where connectivity dimension gap is significantly reduced. In addition, relationship between buyers and producers is altered in the existence of Small Medium Enterprises (SMEs), and the cost of entry to a Global Value Chain (GVC) is cheaper by employing such strategies to specialized in certain stage of value-added creation (Findlay \& Pangestu, 2016) (Kimura \& Chen, 2018). In early 2019, WTO (World Trade Organization) issued Global Value Chain Development Report where trades are analyzed from the perspective of GVC. On the intersection of GVC and digital technology, WTO states that Supply Chain 4.0 includes the implementation of digital technology to reorganize design and planning, production, distribution, consumption and logistics by lead firms (WTO, 2019).

None of industries are unaffected as new business models grow, disruptions in the market, changes in production methods, transportation and systems of delivery (Schwab, 2016). From the view point of GVC, the degree of interdependency between producers and consumers that spread in corners of the globe has increased (Elms \& Low, 2013). This means that global lead firms are no longer positioned as the lone strongest actor in the GVCs but consumers have gained their leverage (Chen,
2017). PwC (Pricewaterhouse Coopers) research found that a third of more than 2,000 respondents say that their companies have been digitizing their supply chains while $72 \%$ others expect to digitize their chains in five years $(\mathrm{PwC}$, 2016). As a result, a key concept of policymaking is based on how to take advantages and response to this wave of Industrial Revolution appropriately.

Similar to previous Industrial Revolution when steam power was introduced to mechanize production; electric power enabled mass production; production processes are automated and computerized, the Industrial Revolution 4.0 offers us countless opportunities and innovations as well as risks and challenges to overcome (Fung, 2013) (Schwab, 2016). In order to thrive, GVCs policy are in greater need to reshaped and improved (Elms \& Low, 2013). This also concerns for civil society actors such as NGOs, national and local governments, labour unions, international organization like International Labour Organization and donor agencies such as World Bank and business people to create value for society by adjusting and reforming their business practices (Fung, 2013) (Gereffi \& Lee, 2018). In the light of this trend, Sustainable Development Goals (SDGs) 2030 is the compass of which all development trajectories should aim for. Environmental costs should be reduced in favour of sustainability and social impacts of production along the GVCs. Accordingly, business strategies can produce innovation and competitive advantages by solving those environmental and societal challenges as the core of their value creation (Porter \& Kramer, 2011) (De Marchi, Di Maria $\&$ Micelli, 2012) (Brandi, 2016). 
Most GVCs scholars tend to focus on economic upgrading in GVCs which is broadly assumed will result in social and environmental upgrading through implications of standardization of production process (Barrientos, Gereffi \& Rossi, 2011) (Bernhardt, 2014). However, it remains unclear on how successful economic upgrading related immediately on better environmental costs and society improvement. Sustainability standards can be described as efforts to solve the dilemma so that attaining economic benefits do not harm environment and society (Brandi, 2016). In agribusiness sector, demand for sustainable GVCs is high. Consequently, in the oil palm industry, lead firms tend to integrate their supply chains to meet demand of global buyers and sustainability regimes (Humphrey \& Memedovic, 2006) (Gereffi \& Lee, 2018). Some major companies that utilize raw material from palm oil such as Unilever, Cadbury, Nestle and others are able to offer traceability and guarantee that their supply chains are sustainably sourced.

Indonesian palm oil value chains have become more integrated, aiming to be more competitive in global markets. To this end, the majority of global trade in palm oil is dominated by a handful companies sourcing from their own estates, smallholders and other grower companies for producing various intermediate or final products. However, for developing countries where often positioned in lower value-added creation compared to developed countries, knowledge transfer and relevant information to entry or experience upgrading in a GVC are not automatic (Humphrey \& Memedovic, 2006). If this issue is not adequately addressed, SMEs are potentially excluded from the value chain. Unable to meet global market demands will isolate those actors like SMEs and small independent farmers with weak bargaining power in GVCs because lead firms, in most GVCs, orchestrates the dynamics as they have strong capital, advanced knowledge of technology, and skill-intensive industries (Gereffi, 2013).

This paper argues that the role of digital technology as a driving force in the Industrial Revolution 4.0 will assist the transformation of GVCs with sustainable principles on its core. To this end, the complexity of Indonesian palm oil value chain will serve as an ideal sector to be investigated further. This is because of power relation in palm oil GVCs is determining factors to secure and conduct economic upgrading without leaving social and environmental upgrading behind.

Supply chain management is transforming. With the vanguard of technology, it is transforming faster, urging all actors to work closely together for society. In the context of Indonesian palm oil industry, this means the role of society and $\mathrm{NGO}$ as driving actors of social and environmental upgrading has been evident. On the other hand, technology has put a considerable amount of pressure to lead firms in regard to transparency and accountability. WTO (2019) defines Value Chain 4.0 as "transforming the model of supply chain management from a linear model in which instructions flow from supplier to producer to distributor to consumer, and back, to a more integrated model in which information flows in multiple directions". This new model of GVCs governance produce coherent challenges and 
opportunities for actors in developing countries to reform their industrial policy.

This paper arranges a research on GVC and cluster framework. The main method used in this paper is desk research, combining descriptive statistics on sectoral and firms' perspective and literature from multidiscipline perspectives to establish social and environmental dimensions. The role of technology in oil palm value chain is highlighted and presented as such: economic upgrading; social and environmental upgrading; fostering sustainable growth through GVC 4.0. Embeddedness of social and environmental upgrading is also discussed with regard to the confluence of actors in GVC and clusters framework.

\section{Theoretical Framework: GVCs and industrial cluster theory}

Global Value Chains (GVCs) framework is developed to explain the process of value creation; gaining, and leveraging those values in all types of industries (Gereffi, Humphrey \& Sturgeon, 2005). The analysis of GVCs governance provides a basis on how power transmits from lead firms and the institutional context in which a set of rules and regulation issued by the government interact in response to market dynamics and global policy. The importance on analysing the governance of GVCs lies in the asymmetrical power exercised by lead firms to its suppliers in terms of how financial, material and human resources allocated within a chain (Nadvi, 2008) (Gereffi \& Fernandez-Stark, 2016). This explains the tendency that lead firms accumulate its power by creating more coordinated and integrated supply chains management to reduce transaction costs. In the case of agribusiness value chain, the global policy is standardization regimes. In agribusiness sector such governance, a type of vertical coordination, is practiced (Humphrey \& Memedovic, 2006).

GVCs framework identify five types of governance - market, modular, relational, captive and hierarchy - in which coexistence between one or two type of governance are common to be found (Gereffi \& FernandezStark, 2016). Market governance involves transactions that are relatively simple requiring little or no formal cooperation between actors so that the central mechanism is price. Modular governance is indicated by more complex transactions which relatively easy to codify. Relational governance occurs when complex information is not going to be easily transmitted or learned between buyers and sellers. Captive governance occurs when the condition of which small suppliers rely on only one or few powerful buyers. Hierarchy governance is a form of vertical integration and managerial control that are developed by lead firms.

Another critical aspect of the analysis is upgrading strategy. Upgrading strategies are employed by actors in GVCs such as countries, regions, suppliers, or any economic actor in order to maintain or improve their positions (Gereffi et al., 2005). Identification of conditions in order to move up to higher chain is essential to experience economic upgrading. For this purpose, multi-stakeholders such as government, business entities and society roles must be taken into consideration to produce necessary commitment and functions for upgrading to occur. The easiest way to 
conceptualize upgrading is a move up from labour intensive to more advanced forms. As more value-added presence in pre- and postproduction services, the intersection of this trend with developed and developing countries as well as location of lead firms' headquarters indicate complex strategy of industrial development. (See Figure 1).

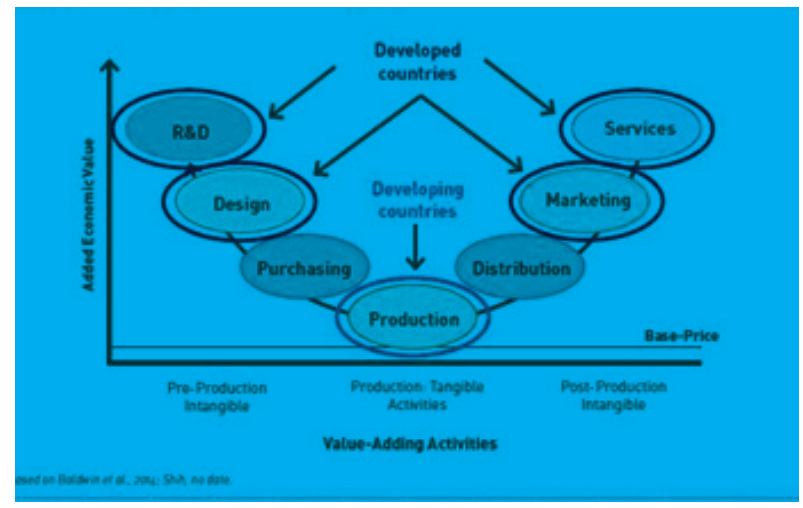

Figure 1. Smile Curve of High-Value Activities in Global Value Chains.

Source: Gereffi \& Fernandez-Stark, 2016

There are four types of economic upgrading - process, product, functional, and chain or inter-sectoral - that have been identified (Gereffi \& Fernandez-Stark, 2016). Process upgrading transforms inputs into output more efficiently by the development of technology. Product upgrading produce a more sophisticated product lines that have higher value added. Functional upgrading occurs when new functions in a chain is acquired or previous functions are abandoned in order to increase their overall skills for the chain. Intersectoral upgrading occurs when knowledge in a particular chain function is used to move into different sectors.

Gereffi and Lee (2018) offer a combination of GVC framework with cluster theory to amplify the result economic upgrading in certain industries. Industrial cluster is an area that geographically link firms, suppliers, service providers and related organizations in a similar sector of industry (Porter, 2003). His example for this concept is IT industries in Austin and Silicon Valley, California. He also argues that industrial cluster is a basic feature of regional and national economies as it has a significant influence on innovation, competitiveness and economic performance. In the context of GVC, governance of industrial clusters helps to contribute to analysis on how cluster firms operate horizontally within local institutional context compared to vertical governance in GVC framework (Gereffi \& Lee, 2018). For this purpose, knowledge production and transfer for economic upgrading; and Corporate Social Responsibility (CSR) activities for social upgrading as well as environmental measures tend to be easily highlighted.

In cluster context, three types of GVCs - private, social, public governance have been observed (Gereffi \& Lee, 2018). Private governance occurs when lead firms through global buyer dictate on how and what products to be made according to quality of private standards regimes. Social and environmental dimensions are addressed also in private standards regime though economic efficiency is on the driver seat by having decentralization systems of productions. Public governance relies on formal rules and regulations issued by local, regional, and national governments. This rules and regulations can support as well as hamper economic upgrading strategies of lead firms indirectly or directly. In social governance, NGOs and labour unions play 
a prominent role by putting pressures in any forms of activism (boycott, petitions, protests) for the implementation of regulations of workers' rights and labour conditions. (See Figure 2).

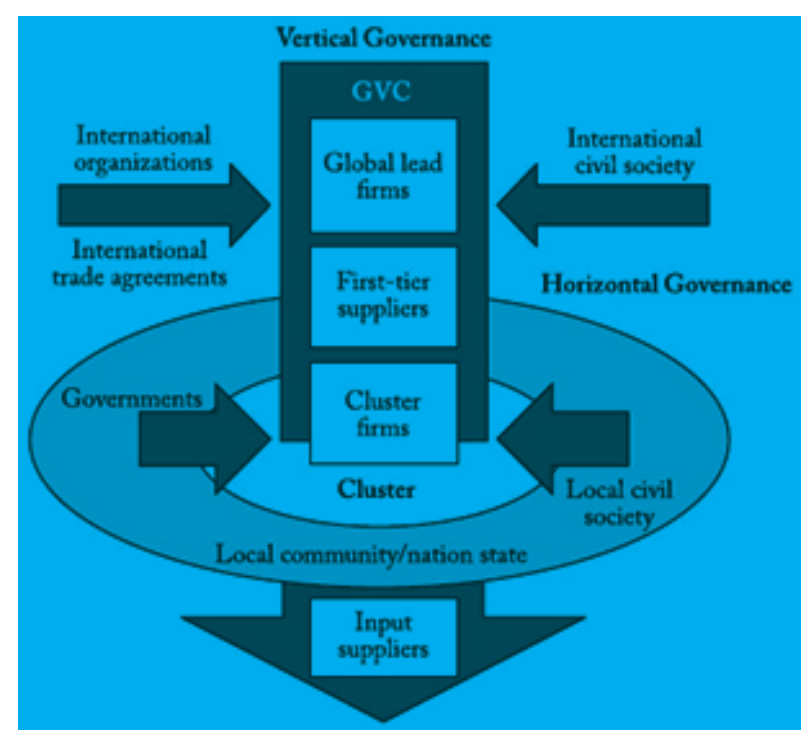

Figure 2. The Confluence of Actors on GVC and Cluster Governance.

Source: Gereffi \& Lee, 2018.

\section{Defining economic, social and environmental upgrading}

No single definition is adequate for defining economic, social, and environmental upgrading in the framework of GVCs. The main reason is that upgrading occurs in multilayered and complex process (Barrientos et al., 2011). However, in general, economic upgrading can be described as 'firms, countries or regions moving to higher value activities in GVCs in order to increase the benefits (e.g. security, profits, value-added, capabilities) from participating in global production' (Gereffi \& Fernandez-Stark, 2016). Another literature suggests that the use of increase in export value unit to explain economic upgrading of a country (Bernhardt, 2014). Notwithstanding, the increase in export value unit may also indicate the cost of production is increased, meaning that international competitiveness is lower.

Determining social upgrading through quantitative indicators is not sufficient even though social upgrading might occur in relation to economic upgrading. In their work, Porter and Kramer (2011) argue that financial benefits for addressing social concern will not be sustainable in comparison to inclusive value creation process. As better work for workers are increased through the rise of wages, enhancing working conditions, protections and rights, there is a correlation that social concerns are reduced. Such conditions will be likely to occurs in certain conditions such as governance structure of GVCs, power relation of union of workers, local ownership, and government policies (Bernhardt, 2014). Another conceptual approach of social upgrading is defined as 'process of improving the rights and entitlements of workers as social actors and enhancing the quality of their employment' (Barrientos et al., 2011).

Environmental upgrading is essential and evident in GVCs of agribusiness products. In order to maintain competitiveness in global markets of agribusiness sector, government need to ensure that producers meet environmental standards in which firms can benefits from reduction of production cost, entry into new markets, and increase bargaining power in the value chains (Humphrey \& Memedovic, 2006) (De Marchi et al., 2012) (Gereffi \& Lee, 2018). Furthermore, novel strategies could be promoted and distributed to actors 
along the chain to answer strict sustainability standards in global market while endorsing for more responsible business practices (Brandi, 2016). Such efforts are also in alignment with Sustainable Development Goals (SDGs) 2030.

\section{Embeddedness of social and economic upgrading: Upgrading trajectories in GVCs and clusters framework}

Social and environmental upgrading expands the reach of CSR (Corporate Social Responsibility) as well as tackles challenges by triggering sustainable innovative strategies. It often assumed that economic upgrading that is related to gaining benefits limited to business actors will produce better social and environmental conditions. However, social and environmental upgrading will be possible and effective through non-corporate efforts influenced and done by NGOs and governments (Gereffi \& Lee, 2018). This also implies that social and environmental upgrading are not necessarily in line with economic upgrading (Barrientos et al., 2011).

Due to various power relations among chains, clusters approach is useful in determining to which directions economic upgrading will foster or prohibit social and environmental concerns to be addressed. To illustrate, CSR measures that is driven by global buyers' pressure only effective to certain degree in their own supply chains without affecting the clusters (Humphrey \& Memedovic, 2006) (Puppim de Olievera, 2008) (Gereffi \& Lee, 2018). Social upgrading also tends to lag behind economic gains (Barrientos et al., 2011). In the light of this concept, Gereffi and Lee recognize six upgrading trajectories - market, CSR, multi-stakeholder initiatives, labour, cluster and governments that expanding the views offered by Pupim de Olievera (2008) to accommodate and evaluate upgrading in the framework of GVCs. These trajectories focus on social upgrading. In my view, environmental upgrading is applicable in such concept as its natures are similar to those of social upgrading.

The first three path of upgrading trajectories are market, CSR, and multistakeholder path. Market-driven path occurs when market demand is high including both social and environmental standards so that firms seek to maintain their competitiveness through product and process differentiation in exchange for market incentives. CSR-driven path is driven by 'an act of compliance' to comply with social and environmental regimes, avoiding brand and reputational damage for lead firms while maintaining access to global markets and suppliers for cluster firms. Multistakeholder path calls for cooperation model which include multiple stakeholders such as national government, clusters institution, (and) local firms combining capacity building with compliance monitoring and sanctions to address social and environmental concerns.

The other three upgrading paths are labour-centred, cluster-driven, and public governance. Labour-centred path emphasize on the role of workers and labour unions that are able to put pressure to firms like global buyers so that they undergo upgrading strategies. Cluster-driven path offers bottomup approach of upgrading where cluster firms that are inserted in a global value chain collectively improve working conditions 
within the clusters. In public-governance path state exercise its power to enforce the law and regulations through various agency in different levels of government under their jurisdictions reaching beyond one or two clusters. Similar to concept of GVC governance frameworks, these six trajectories for social and environmental upgrading can coexist and bound to one to few trajectories. (See Figure 3).

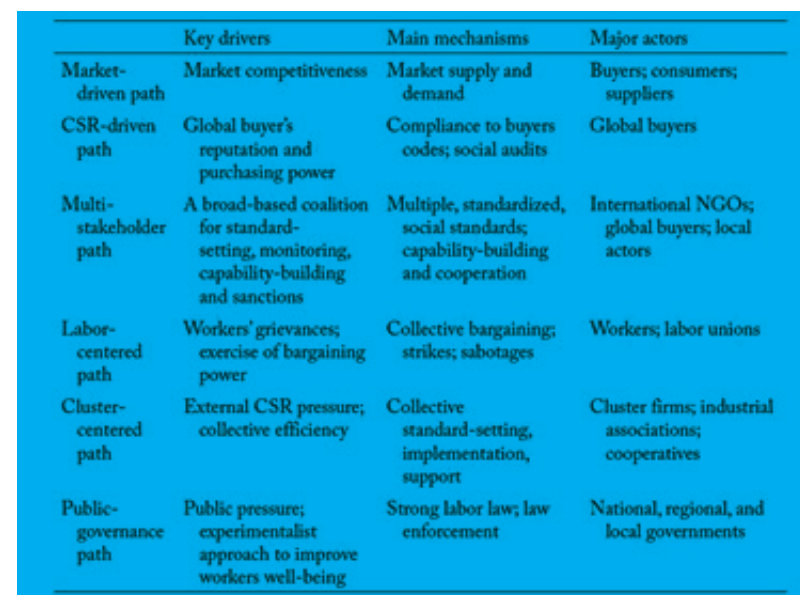

Figure 3. Key Drivers, Mechanisms,

Major Actors of Social and Environmental Upgrading.

Source: Gereffi \& Lee, 2018

In this paper, these frameworks will be applied to analyze how palm oil industry in Indonesia response to the Industrial Revolution 4.0. Palm oil sector is lucrative in terms of the amount of money and the number of workers and its contribution to Indonesian GDP. It irrefutably generates social tensions and environmental backlashes as well. Thus, the role of digital revolution is critical to be examined in relation to its application and implication from all actors along the value chains; and how it influences the governance dynamics of palm oil.

Palm oil lead firms in Indonesia consists of several homegrown companies that list in Singaporean and Malaysian stock exchanges. For example, Golden AgriResources (GAR), the largest producer of CPO in Indonesia, is Sinarmas Group subsidiary listed on Singaporean stock exchange (TuK, 2018). With others major companies, their accumulated capital and networks dictate the governance of palm oil value chain. In this paper, such relationships are examined through hierarchy and captive governance while in the horizontal locus of local actors (government, civil society and non-government organization) are taken into account.

In the literature of $\mathrm{GVC}$ economic upgrading, many suggest that four upgrading categories - process, product, functional and intersectoral - are carried out sequentially, one after another (Kaplinsky $\&$ Morris, 2015). In the light of this, this paper attempts to map these four types of upgrading adequately to a certain degree. On the other hand, special emphasize is put on the utilization of technology in process and product upgrading. Therefore, it is essential to draw Indonesia as global palm oil producer that still lack in processing capabilities and product variety due to lack of strategic industrial policy.

\section{Indonesian palm oil: an overview}

In Palm oil as one of Indonesian top export commodities delivers opportunities to gain value-added that is going to contribute to reduce the country's trade deficit. According to International Trade Centre (ITC), utilizing data from UNCOMTRADE database in 2017, 
Indonesia is a leading export on palm oil (HS 1511 ) with $54.1 \%$ of share in world export. In quantity, 22.8 million tons of Indonesian palm oil are exported compared to 9,6 million tons of Malaysian palm oil as the second top exporter (ITC, 2019). Plantation sector in which palm oil is the major value input contribute $3.47 \%$ of Indonesian GDP in 2017. Since the late 1990s, Indonesia began to replace Malaysia's position as the largest exporter of palm oil (Cramb and McCharthy, 2016). Indonesia considers palm oil as a driving force for economic performance improvement in order to increase GDP contribution, as well as other important sectors such as employment, export gains, and rural development.

Plantation ownership of palm oil in Indonesia that is divided into three categories with total 31 million hectares (Statistics Indonesia, 2017). First, private sectors including multinational companies and its subsidiaries owns $57.70 \%$ palm oil estate in the country. Second category is smallholders whose ownership accounted for $39.90 \%$. The last category is plantation managed by state companies which has the smallest percentage, $5.40 \%$. In fact, official data on palm oil industry is unsynchronised and thus different from one ministry to another ministries or state agencies. However, data on ownership schemes could resonate how power asymmetrical is preserved in governance of Indonesian palm oil.

Palm oil business model influence the policy dynamics. The number of smallholders and medium-scale plantations have been growing significantly (Pacheco, Gnych,
Dermawan, Komarudi \& Okarda, 2017). In Kalimantan, the majority of plantations are industrial scale while in Sumatera smallholders tend to dominate. According to van Noordwijk et al. (2017), it depends on how the contract agreements that are facilitated by government or company, smallholders can then be categorized as independent - outgrowers - if they can transport fresh fruit bunches (FFBs) to mills directly. In other cases, nucleus estate - plasma schemes emerge with proportion that is $80 \%$ owned by the company while $20 \%$ of the land is reserved for smallholders. In practice, most companies choose to manage all of the plantation giving smallholders only share of dividend which are often without transparency.

The government of Indonesia issued Government Order No. 14 Year 2015 on Master Plan of National Industry Development (RIPIN) that lists palm oil along with rubber, seaweed, and pulp and paper on strategic industries with high competitive advantages. In the same document, the government also acknowledges the development of palm oil downstream industries is limited which is shown by Crude Palm Oil (CPO) as main export of palm oil products (Ministry of Industry (MOI), 2015). Technically speaking, $\mathrm{CPO}$ is neither end product of palm oil industry nor intermediate product because processing FFBs into CPO is still categorized in upstream activity. Roughly $80 \%$ of palm oil derivatives are used in food products from ice cream to cooking oils (Tong, 2017). Other uses of palm oil products include animal feeds, paper, fertilizer and other non-edible uses. (See Figure 4.) 


\begin{tabular}{|c|c|c|c|}
\hline Stage & Key segment & Segment description & Product \\
\hline Upstream & $\begin{array}{l}\text { - Input supply } \\
\text { - Plantation } \\
\text { - Milling \& crushing } \\
\text { (primary } \\
\text { processing) } \\
\text { - Waste and } \\
\text { Residue } \\
\text { Management }\end{array}$ & $\begin{array}{l}\text { - Produce and distribute goods } \\
\text { that planters use for their } \\
\text { production activities } \\
\text { - Grow and harvest fresh fruit } \\
\text { bunches (FFBs) } \\
\text { - Process FFBs into crude palm oil } \\
\text { (CPO) and crude palm kernel oil } \\
\text { (CPKO) } \\
\text { - Convert biomass wastes and } \\
\text { residues into further uses }\end{array}$ & $\begin{array}{l}\text { - Machinery/equipment } \\
\text { - } \text { Agrochemicals } \\
\text { - } \text { Seedtilizer } \\
\text { materials } \\
\text { - } \text { FFBs } \\
\text { - CPO } \\
\text { - CPKO } \\
\text { - Palm Kernel Cake (PKC) } \\
\text { - Electricity } \\
\text { - By-products (e.g. } \\
\text { fibreboards) }\end{array}$ \\
\hline Midstream & $\begin{array}{l}\text { - Trading } \\
\text { - Transport \& } \\
\text { logistics } \\
\text { - Basic refining } \\
\text { (secondary } \\
\text { processing) }\end{array}$ & $\begin{array}{l}\text { - Trade palm oil onwards on } \\
\text { domestic and export markets } \\
\\
\text { - Coordinate transportation, } \\
\text { storage and delivery of goods } \\
\text { - Refine and fractionate crude } \\
\text { products into a wide range of } \\
\text { basic processed palm oil (PPO) } \\
\text { and processed palm kernel oil } \\
\text { (PPKO) products }\end{array}$ & $\begin{array}{l}\text { - } \\
\text { - Service } \\
\text { - Service } \\
\text { - Main PPOs: refined, } \\
\text { bleached, deodorised } \\
\text { (RBD) palm oil; RBD } \\
\text { palm olein; RBD palm } \\
\text { stearin } \\
\text { Main PPKOs: RBD palm } \\
\text { kernel oil; RBD palm } \\
\text { kernel olein; RBD palm } \\
\text { kernel stearin } \\
\text { - Palm fatty acid distillates } \\
\text { (PFAD) and palm kernel } \\
\text { fatty acid distillates (by- } \\
\text { products from refining) }\end{array}$ \\
\hline Downstream & $\begin{array}{l}\text { Further refining } \\
\text { (secondary } \\
\text { processing) }\end{array}$ & $\begin{array}{l}\text { - Further process PPO and PPKO } \\
\text { into intermediate or finished } \\
\text { products } \\
\\
\text { - Produce consumer goods using } \\
\text { palm oil derivatives as } \\
\text { functional ingredients or } \\
\text { processing aids }\end{array}$ & $\begin{array}{l}\text { - Edible oils } \\
\text { - Specialty fats } \\
\text { - Oleochemicals } \\
\text { - Phytol } \\
\text { - Food products } \\
\text { - Personal and household } \\
\text { care products }\end{array}$ \\
\hline
\end{tabular}

Figure 4. Simplified of Palm Oil

Global Value Chain.

Source: Tong, 2017 
Another factor to consider is oligopolistic nature of palm oil global value chain in which multinational corporations: Sime Darby, Felda, Golden Agri Resources (GAR), Asian Agri, Musim Mas, and Wilmar which listed on Malaysian, Indonesian and Singaporean stock exchanges control upstream, intermediate and downstream activities (Pacheco, et al., 2017). These companies operate downstream industries in importing countries in Europe, China and the US. For example, Wilmar, Musim Mas, GAR, IOI Corporation, and Kuala Lumpur Kepong (KLK) are the world's major players controlling $87 \%$ of global trade in palm oil in 2014 including buying from thirdparty suppliers such as smallholders or other grower companies in order to trade in various intermediate or final products (Nesadurai, 2017). This can be seen from the fact that 10 largest Malaysian palm oil companies including state-owned companies that own plantation outside Malaysian territory have $86 \%$ of their plantation estates in Indonesia (Tong, 2017). In this regard, there is approximately $25-50 \%$ of Malaysian interests present in Indonesian palm oil industry (Varkkey, 2016).

\section{Sectoral upgrading: the role of technology}

The advancement of technology let developing countries to experience leapfrogging in which adoption of technology allows developing countries to leap, bypassing some stages, so that developing countries can catch up with leading countries by acquijring, mastering and adapting new products, technologies or managerial structures (Lee and Mathews, 2013). According to Indonesia Industry 4.0 Readiness Index (INDI 4.0) compiled by Ministry of Industry in 2019, from 328 companies surveyed, big scale industries including food, electronics, constructions, and textile scored on average 2.47 of maximum 4.0 on the scale. This index implies that some major industries, notably food industry as it is related with palm oil, are on the verge of utilizing digital technology in their value chain. Global value chain of palm oil shares similar characteristics to those of commodities-based value chain such as mining products, oils and ore metals and minerals that some countries export their raw products with low value added to importing countries where downstream activities are conducted. Taking into account all these factors, palm oil industry experiences a rise in efficiency and productivity with support of technology relying more in services sectors in the chain while dealing with structural problems such as uncoordinated horizontal policies (Arfani \& Winanti, 2014) (Findlay \& Pangestu, 2016). Arfani and Winanti (2014) have identified that Indonesian pam oil industry have been undergoing process, product, functional and intersectoral upgrading.

Golden Agri Resources (GAR) is one of global players of palm oil and has the largest plantation in Indonesia that illustrate how upgrading trajectories are undertaken from lead firms' perspective. The company has 498,395 thousand hectares of palm oil plantations in several provinces. Furthermore, GAR has a high production capacity (46 mills extracting 13,3 million tons of CPO and Palm Kernel (PK) per annum) and related facilities such vessels, warehouses in several countries and extensive trading networks (GAR, 2018). In regard to their annual report, GAR has been conducting 
process and product upgrading by developing seeds with high fruit yield and oil extraction ratio to intensify their production. Their palm oil yields per hectare from their plantations increased from 5.7 tons per hectare in 2017 to 6.2 per hectare in 2018. In comparison, smallholder's plantation in average only produce 3 to 4 tons per hectare.

Technology allows palm oil to be used as component of biodiesel. Around 13 percent of palm oil output is used for biofuel (Rival \& Levang, 2014). For instance, Brazil has a successful biofuel program to be used domestically and export producing bioethanol from sugar cane crops due to superior high yields (Lee \& Mathews, 2013). On the other hand, Indonesia has just commenced its mandatory biodiesel program, Public Service Obligation, to blend fossil fuel and palm oil partly to response restrictions on global market especially European Union(USDA, 2018). New catalyst that is called Merah Putih, developed by a research team from Bandung Institute of Technology (ITB) producing better mixture 12.5 percent of refined, bleached, deodorised of palm oil (RBDO) with fossil fuel (Ministry of Research, Technology and Higher Education, 2019). This shows that Indonesian palm oil has attained in certain degree functional and intersectoral upgrading.

Indonesia Oil Palm Plantation Fund Management Agency (BPDPKS) is a government body under Ministry of Finance that collect fund - CPO Supporting Fund from palm oil and its derivatives products exports tariffs and others fund from palm oil companies. This agency has several functions that some of them are promoting research and development, conducting replanting to increase productivity and educating public on palm oil (BPDPKS, 2018). However, since its creation in 2015, BPDPKS has been criticised for the use of the fund to primarily support biodiesel industry rather than prioritising replanting program for smallholders (Kompas, 2019). Thus, research and development of palm oil industry is neglected, making the role of government is weak incomparable those of private companies in utilizing technology. In contrast, Malaysian Palm Oil Broad (MPOB) has been playing a central role in reporting, regulating and monitoring as well as conducting research on Malaysian palm oil industry that involve a strong collaboration with private firms (Tong, 2017).

Industrial development policies in Indonesia aim to create international competitiveness in order to target all activities in the chain or specific ones to benefit from world's economy (Tijaja \& Faisal, 2014). Since the downfall of New Order's regime in 1998, a degree of power has been transferred to city or regency government. This creates palm oil governance that places city or regency government in a strategic and influential level (Gillespie, 2016). Still, Jakarta is able to exercise its power through Presidential Instruction No. 8 Year 2018 that halt new land acquisition for palm oil plantations. The government instead urge to focus on development of downstream segments and related industries such as oleochemical and biodiesel. Nonetheless, global companies like GAR manages to expand their plantations outside Indonesia by acquiring lands in Africa.

Integrated industrial complex are 
being built in order to increase efficiency and capture more value-added in downstream activities. This effort is apparent in order to give incentives to companies that expand their refining capacity. The new industrial integrated industrial complexes are located in special economic zones (KEK) which means tax levies are imposed as tools to attract investors (Ridhwan et al., 2015). KEK Sei Mangkei in North Sumatera has an Innovation and Research Centre of Palm oil. However, how significant of KEK that is supported by a dedicated research centre to the governance dynamics of palm oil is open to question.

\section{Social and environmental upgrading: power asymmetry remains}

Observing power asymmetry relies on the fact that power is accumulated in a handful of actors through capital and political network. These constellations of power network are featured in GVC governance. Kaplinsky and Morris (2015) argue that an increasing concentration of buyers might lead to asymmetrical power relation between suppliers. In other words, governance structure of a value chain is dominated by lead firms (Gereffi and Fernandez-Stark, 2016). In the case of palm oil value chain, emerging issues of sustainability regarding social and environmental issue have become the arena of struggles in the realm of certain institutional contexts.

Environmental issues arise in palm oil industry that begin from land clearing for new or expansion of plantation of various scale. A large scale of land clearing occurs when palm oil plantation estates are being built in forest areas so that ecosystem and biodiversity as well as water quality are damaged (Pacheco et al., 2017). Moreover, environmental impacts will be heavily influenced by land use prior to land use change into palm oil plantations (Gunarso, Hartoyo, Agus \& Kileen, 2013). Such issues have attracted concerns from the European Union (EU), the third largest major importer of Indonesian palm oil, that categorized Indonesian palm oil as 'unsustainable high risk' due to framework set by the EU, Indirect Land Use Change (ILUC) (EU, 2019).

A significant point to note is that European Union (EU) has a leading role in producing a set of rules, Directive (EU) 2018/2001 supported by Delegated Regulation No. C (2019) 2055 Final High and Low ILUC Risk Criteria on biofuels that plan to rule out palm oil as biofuel component by 2030 (EU, 2019). In response, Indonesian government plan to retaliate and bring the case to WTO Dispute Settlement, claiming EU imposing trade restrictions on palm oil. However, in my view, this issue is deeply politicized by both parties to only trade issue, overshadowing core environmental and social issues.

Palm oil expansion is accused as the culprit of deforestation in Indonesia. A study from Vijay, Pimm, Jenkins and Smith (2016) found that from 2008 to $2015,54 \%$ of Indonesia forest had been converted into palm oil estates. Although, in general, there are some drivers of deforestation such as logging, grazing or other crops, palm oil expansion accounted by $59 \%$ of deforested areas between 1990 and 2008 (Cuypers et al., 2013). Forest loss that is done by burning or other methods in palm oil concessions is apparent in Kalimantan compared to Sumatera as many large scales 
land clearing in the former while the latter has more mature plantations (Carlson et al., 2012) (Curtis et al., 2018). Furthermore, haze problems emerge as transnational concerns that reached a peak in 2015 with 2,6 million hectares were burnt, a third of which were in peatlands (Pacheco et al., 2017).

However, there is a lack of studies that observe systematically the relation between biodiversity loss and species richness with palm oil expansion. Savilaakso et al., (2014) found that from 1,201 articles on the theme of the effect of palm oil and biodiversity loss, only 25 articles conducted in rigorous methods. This finding, however, does not rule out the fact that there is a correlation of deforestation driven by any causes, particularly palm oil expansion, with species richness and biodiversity. Similarly, World Wild Fund for Nature (WWF) has highlighted that Orangutan natural habitat, in Kalimantan and some Sumatra forests, are severely damaged (WWF, 2019).

By far, power asymmetry begins to materialized evidently in alleged social concerns. Social issues have been prevalent in the process of land acquisitions. These agrarian conflicts occur as investment from lead firms are encountered with rejection of land use change in customary lands, and sacred sites such as burial sites (Levang, Riva \& Orth., 2016). Land entitlements are often unclear so that conflicts between companies and customary landholders who consider land grabbing are done unfairly usually without free prior and informed consent (FPIC) manner leaving traditional landowners vulnerable to be exploited. (Obidzinki, Andriani, Komarudin \& Adrianto, 2012) (Li, 2015). For conflicts that are undergoing judicial process, it is the companies supported with political patronage networks, bribery and other resources that often win the cases. This is worsened by insufficient legal framework (Pichler, 2015). To such an extent, the role of government is insignificant in solving this issue.

The repercussions of social tensions of plantation workers is pervasive as diverse business models and a lack of systematic studies on this topic. Employment issues include "limited access to plantations jobs, unemployment among former landholders, payment of wages below provincial minimum, and the prevalence of casual, subcontracted, temporary workers" (Li, 2015, p. 5). In general, permanent workers obtain better income than casual workers who paid daily (Pacheco et al., 2017). Plasma farmers also receive regular monthly compared to independent farmers due to low yields (Zen, Barlow, Gondowarsito \& McCarthy, 2016). Indonesian government claims that 16.2 million people make a living from palm oil plantation with 4.2 million direct labours and the rest 12 million considered as indirect workers.

Institutional contexts of global value chain governance of palm oil are characterized by sustainability standard regimes. The Roundtable on Sustainable Palm Oil (RSPO), a private sustainability regime, has been emanating to be the forefront addressing social and environmental concerns without government regulations (Pye, 2015) (Nesadurai, 2017). Brandi (2016) notes that RSPO only as a mean of solving dilemma between economic interests and social and environmental issues in which also create another dilemma in the 
process of implementation.

As a 'ticket' to global market, RSPO is costly so that only big companies and its subsidiaries can meet RSPO auditing process. Smallholders that are considered as suppliers in which they supply FFBs to lead firm supply chain like Sinarmas, they participate in weak manner because of captive selling structure. This means rather than processing FFBs into CPO, they tend to sell FFBs directly to companies' mills. Due to captive and hierarchy governance of value chain, smallholders have limited economic benefits in regard to improving quality of FFBs because they have only implemented RSPO criteria imposed by RSPO mills they sell to (Brandi, 2016). Some mills, however, offer better pricing schemes for smallholders with RSPO certification while some other mixed their input with those have been standardised to non-standardised due to remote area of plantations and processing facilities (Nesadurai, 2017).

Similarto RSPO, Indonesian Sustainable Palm Oil (ISPO) is an official respond from the Government of Indonesia to redress emerging issues in palm oil. However, ISPO success is derailed as several aspects of ISPO such as legal land entitlements are in conflict with legal status of forest area and costly auditing process, hampering the certification process particularly for independent smallholders (Bisnis, 2019). Moreover, according to Zen et al., (2016), the Government of Indonesia has only been doing 'micro-interventions' consisting provision of infrastructure and services, and targeted programs such as improvement of individual smallholdings which mostly ineffective owing to decentralized political control.

\section{Fostering sustainable growth through GVC 4.0}

The utilization of technology is essential to address lingering structural problems that is data synchronisation. Corruption Eradication Commission (KPK) in 2016 has identified three core structural problems - ineffective export cost structure and poor tax management - in palm oil industry one of which is land concessions management and accountability of business entity (KPK, 2016). Using an overlay digital map, KPK found that land concessions given to palm oil companies or smallholders are overlapping with land concessions for other purposes such as protected forest areas, national parks, conservation areas, mining, and peatlands. As a result, more integrated maps that is generated through Geographical Information System (GIS), are important in order to manage and monitor land concessions for palm oil plantations. For that reason, recently, the government of Indonesia plan to launch Satu Peta Sawit Nasional (An Integrated Map of Land Concessions) by the end of this year (Katadata, 2019).

Landscape management is another concept to approach sustainable palm oil that can be considered as multi-stakeholders driven path. This concept is offered by Aidenvironment, a project under The Sustainable Trade Initiative (IDH) and The Netherlands Oils and Fats Industry (MVO) (ESPO, 2019). Desk research, the collection of satellite images and drone footages for geographical and agricultural information and continuous monitoring are conducted in collaboration with palm oil companies, local governments, NGOs and villages in landscape level. A spatial planning that is aimed to protect natural resources or wildlife as well as for 
villagers to obtain economic benefits while waiting for palm oil to bear fruits in five years is designed. However, challenges remain in the area of policymaking concerning to government institutions sectoral discrete.

Major social, environmental and economic upgrading trajectory in palm oil industry is market-driven path. Market-driven path also accommodates consumers growing demand of sustainable products such as the case of fresh produces in European market by specifying how products should be grown, harvested, and transported (Humphrey \& Memedovic, 2006). A case point is that when Genetically Modified Organism (GMO) imported from the US to European market in which European public were sceptical and ultimately gave special labels to GMO products (Pollack \& Shaffer, 2009).

Traceability leads to transparency by putting global pressure to companies to adhere to sustainable practices through campaigns or investigative reports. In order to urge the companies to consistently ensure traceability of their chain, strict monitoring from related stakeholders and constant pressure from NGO might be the key. Technically speaking, traceability of the palm oil value chain is possible because public can trace palm oil supply chain to mills with $24-48$ hours driving distance since FFBs only stay fresh for one or two days (ESPO, 2019). This also means that horizontal governance through locally CSR-driven upgrading should be encouraged to monitor and supervise the implementation because relying on RSPO regime only might lead to 'greenwash' practice of those companies for protecting brand image (Pye, 2016).
From firms' perspective, Certified Sustainable Palm Oil (CSPO) are not always sold in the market due to more expensive than non-CSPO and low demand for CSPO products in major consumers such as India and China (The Japan Times, 2019). Therefore, providing that various modes of production especially in regards to smallholders' FFBs inputs and geographically dispersed, challenges remain to implement consolidated model of traceability (Jelsma et al., 2017). This paper argues that while technical schemes might be an issue to solve in the future, it is the political will of every level of governments that could be a promising start to foster sustainability of palm oil industry.

On the other hand, weak upgrading trajectory is public-governance path partly due to uncoordinated policies and poor law enforcement. To illustrate, in Malaysia, Federal Land Development (FELDA) successfully promoted its poorer citizens interests while growing international competitiveness and growth in the sector (Zen, et al., 2016). In comparison, Zen, et al (2016) notes that Indonesia has different political and technical context, decentralized system, extensive and agroclimatic difference across islands while Malaysia has more centralized and powerful political system. In this case, Bupati (Regent) has a leading role who decide and influence palm oil governance in their territories as to whether enough budgeting, capable civil services and sound poverty alleviation programs are in place in order to secure the interests of smallholders (Gillespie, 2016). As a result, in many areas, the role of government is mostly absent.

In the wake of digital technology, governments at national and local levels 
launch e-Government initiatives in order to increase efficiency and productivity. At national level, Presidential Staff Office (KSP) has two e-Government related projects which are Satu Data (One Data) and Satu Peta (One Map). Provincial and city or regency level adopt similar approach with some adjustments according to their needs. Unfortunately, there is a lack of studies to thoroughly evaluate and measure its effectiveness. In fact, this could potentially create a paradox if bureaucracy is not reformed (Lee, 2011). Drawing from e-Government concept and practices in Korea, Lee (2011) emphasises that formulation and implementation of e-Government aim to connect industrial development, foster businessfriendly environment while contributing to economic development. To this end, Bupati (Regent) leadership is necessary for creating and monitoring pro-poor programs for farmers or smallholders as it is evident in Siak district, Riau (Zen et al., 2016).

Cluster and labour-centred trajectory for economic, social and environmental strategy is often undermined. This concept emphasises on collective actions of clusters actors that is built by trust and mutual dependent between them (Gereffi \& Lee, 2018). Plessis and Rautenbach (2009) argued that cultural aspects are as significant as other aspects such as environmental, economic, and social in the framework of sustainable development. To exemplify, expansion of palm oil estate in Kalimantan often generates conflicts with customary landholders, Dayak Tribe as legal framework is ineffective in recognising such rights or rejection of land conversion into palm oil (Levang et al., 2016). A success in obtaining these rights and securing customary lands to be preserved and managed by local villagers will lead to collaborative actions toward sustainability (Dewi, 2013). Local communities can also depend on their customary forests for making a living from its products as alternative incomes than palm oil. However, it is important to note that firms do not exercise its power to make local communities surrender their lands. Instead, firms offer them choices as to whether they want to sell or manage palm oil plantation on their own.

Another collaborative actions from cluster actors can be seen from a story of a village cooperative (KUD) Tani Subur in Kotawaringin Barat, Central Kalimantan. Setiyana, the head of Tani Subur, has successfully transformed Tani Subur into sustainable cooperative in terms of economic, social, and environmental aspect despite only a few farmers joined the cooperative in the beginning. It generates billions of rupiah from its palm oil business, agritourism and cows that feed on palm oil waste (Borneonews, 2019). Tani Subur also facilitate its member by giving training and credits for certification process. Moreover, it also has attracted some of best local students who study in major cities to come back to contribute and play crucial role in the development of their local communities. Thus, cluster-driven path is evidently and likely to more successful as it is a bottom-up approach compared to adhering to only RSPO as social and environmental upgrading trajectory.

The Industrial Revolution 4.0 is a driving force for creating GVC 4.0. It offers traceability and transparency as the cost of communication is reduced and administrative 
works are digitized. In palm oil sector, as it has been discussed, demonstrate how all actors in the value chain amplify their roles thus gaining more influence to governance dynamics. Although, the implication so far is limited to be assessed in case by case basis. This is due to numerous business model and governance in palm oil sector. Nevertheless, with the support of technology, social and environmental issues in the industry can be redress one by one for fostering sustainable growth in the near future.

\section{Conclusion}

This paper has demonstrated that economic, social, and environmental upgrading trajectories occur in every trajectory of GVCs and cluster framework of palm oil industry in Indonesia. Some upgrading trajectory are dominant such as market-driven and multistakeholders path while CSR-driven, clusterdriven, labour-centred, and public-governance path are weak due to various factors. For firms, financial incentives are the main driver for their upgrading purposes while policymakers find it hard to consolidate powers due to decentralized political systems and discrete sectoral block within government agencies. It is worthnoting that some Bupati (Regent) have taken advantages of the status quo by generating propoor programs with capable civil services and strict monitoring.

The vanguard of digital technology foster traceability and transparency along with its industrial usages that is increasing productivity and efficiency in process and product upgrading, in the palm oil value chain. This can then be categorized that global consumers in vertical governance of value chain gaining leverage to put pressure to global lead firms that is evident from the case of European market even though political dimension of this issue is apparent. From horizontal governance, both central and local government in Indonesia have launched several e-Government initiatives in palm oil sector. Technology role is also critical in upstream stage of governance related to land concessions in order to avoid agrarian conflicts in the future. However, further researches have to scrutinize how these initiatives support the principal bureaucracy reform agenda if power asymmetry is still apparent.

Technological wave in the Industrial Revolution 4.0 is essential to foster sustainable palm oil. All actors including firms, workers and communities as well as governments along the chain can reap the benefits by solving the constraints namely political, technical, and structural dimensions with their roles (Bair, 2005). Despite of new potentials from the role of technology has to offer, the challenges remain when unsustainable practices, power imbalance and existing business value creation persists. Therefore, social and environmental dimensions are not supposed to be a glossy finish in business particularly in agribusiness sector but it has to be its core practice principally in inclusive efforts to provide global market access for SMEs and small independent farmers (Humphrey \& Memedovic, 2006). In the light of this, a strong linkage between actors suggests that the Industrial Revolution 4.0 is relevant and essential to enhance synergy to cater for economic, social and environmental dimensions in order to harness the potential of sustainable development. 


\section{References}

\section{$\underline{\text { Books }}$}

Baldwin, R. (2016). The great convergence: information technology and the new globalization. Massachusetts, USA: The Belknap Press of Harvard University Press.

Bernhard, T. (2014). Economic and Social Upgrading of Developing Countries in the Global Apparel Sector: Insights from Using a Parsimonious Measurement Approach. In Rossi, A., Luinstra, A., \& Pickles, J. (Ed.). (2014). Towards Better Work. Hampshire, UK: Palgrave Macmillan and International Labour Office.

Cramb, R., \& McCarthy, J. F. (2016). Characterising Oil Palm Production in Indonesia and Malaysia. In Cramb, R., \& McCarthy, J. F. (Ed.). (2016). The Oil Palm Complex: Smallholders, Agribusiness and the State in Indonesia and Malaysia. Singapore: NUS Press.

Dewi, O. (2013). Reconciling Development, Conservation, and Social Justice in West Kalimantan. In Pye, O., \& Bhattacharya, J. (Ed.). (2013). The Palm Oil Controversy in Southeast Asia: A Transnational Perspective. Singapore: ISEAS Publishing.

Gereffi, G., \& Lee, J. (2018). Economic and Social Upgrading in Global Value Chains and Industrial Clusters: Why Governance Matters. In Gereffi, G. (2018). Global Value Chains and Development
Redefining the Contours of 21st Century Capitalism. Cambridge, UK: Cambridge University Press.

Gillespie, P. (2016). Oil Plantations and Conflict in Indonesia: Evidence from West Kalimantan. In Cramb, R., \& McCarthy, J. F. (Ed.). (2016). The Oil Palm Complex: Smallholders, Agribusiness and the State in Indonesia and Malaysia. Singapore: NUS Press.

Levang, P., Riva, W.F., \& Orth, M. G. (2016). People, Participation, Power: The Upstream Complexity of Indonesian Palm Oil Plantation. In Cramb, R., \& McCarthy, J. F. (Ed.). (2016). The Oil Palm Complex: Smallholders, Agribusiness and the State in Indonesia and Malaysia. Singapore: NUS Press.

Pollack, M.A. \& Shaffer, G. C. (2009). When Cooperation Fails: The International Law and Politics of Genetically Modified Foods. New York, USA: Oxford University Press.

Puppim de Oliveira, J. A. (2008). Introduction: Social Upgrading among Small Firms and Clusters. In Puppim de Olievera, J. A. (Ed.). (2008). Upgrading Clusters and Small Enterprises in Developing Countries: Environmental, Labour, Innovation and Social Issues. Surrey, UK: Ashgate Publishing Limited.

Pye, O. (2016). Deconstructing the Roundtable on Sustainable Palm Oil. In Cramb, R., \& McCarthy, J. F. (Ed.). (2016). The Oil Palm Complex: 
Smallholders, Agribusiness and the

State in Indonesia and Malaysia.

Singapore: NUS Press.

Varkkey, H. (2016). The Haze Problem in

Southeast Asia: Palm Oil and

Patronage. New York, USA:

Routledge.

Zen, Z., Barlow, C., Gondowarsito, R., \& McCarthy, J. (2016). Interventions to Promote Smallholder Oil Palm and Socio-economic Improvement in Indonesia. In Cramb, R., \& McCarthy, J. F. (Ed.). (2016). The Oil Palm Complex: Smallholders, Agribusiness and the State in Indonesia and Malaysia. Singapore: NUS Press.

\section{Report}

Arfani, R. N., \& Winanti, P. S. (2014). Value chain governance in export commodities: the case of Indonesia. In Jansen, M., Jallab, M. S., \& Smeets, M. (Ed.). (2014). Connecting to global markets Challenges and opportunities: case studies presented by WTO chairholders. Geneva, Switzerland: WTO Publications.

Chen, L. (2017). Developing Asia in the Era of Cross-border E-commerce. Economic Research Institute for ASEAN and East Asia (ERIA) Discussion Paper series. Retrieved from http://www.eria.org/ERIADP-2017-11.pdf

Corruption Eradication Commission (KPK). (2016). Kajian Sistem Tata
Kelola Komoditas Kelapa Sawit. Retrieved from https://acch.kpk. go.id/id/ component/bdthemes shortcodes $/$ ? view $=$ download\&id= 59 a f 58964 c c b 675 c b a 88 d349c3775d

Cuypers, D., Geerken, T., Gorissen, L., Peters, G., Karstensen, J., Prieler, S., ... van Velthuizen, H. (2013). The impact of EU consumption on deforestation: Comprehensive analysis of the impact of EU consumption on deforestation. European Commission Technical Report. DOI: 10.2779/822269

Elms, D. K., \& Low, P. (Ed.). (2013). Global value chains in a changing world. Geneva, Switzerland: WTO Publications.

Fung, V. K. (2013). Governance through partnership in a changing world. In Elms, D. K., \& Low, P. (Ed.). (2013). Global value chains in a changing world. Geneva, Switzerland: WTO Publications.

Golden Agri Resources (GAR). (2018). Annual Report 2018. Retrieved from https://goldenagri.com.sg/wpcontent/uploads/2019/04/GARAR-2018_final_LowRes.pdf

Gunarso, P., Hartoyo, M. E., Agus, F., \& Kileen, T. J. (2013). Oil Palm and Land Use Change In Indonesia, Malaysia And Papua New Guinea. Reports from the Technical Panels of the 2nd Greenhouse Gas Working Group of the Roundtable on Sustainable Palm Oil (RSPO) 
Lee, K., \& Mathews, J. (2013). Science, technology and innovation for sustainable development. United Nations Department of Economic \& Social Affairs CDP Background Paper No. 16. Retrieved from https://www.un.org/development/ $\mathrm{desa} / \mathrm{dpad} / \mathrm{wp}$-content/uploads/ sites/45/publication/CDP bp-2013-16.pdf

Li, T. M. (2015). Social impacts of oil palm in Indonesia: A gendered perspective from West Kalimantan. Center for International Forestry Research (CIFOR) Occasional Paper 124

Pachecho, P., Gnych, S., Dermawan, A., Komarudin, H., \& Okarda, B. (2017). The palm oil global value chain: Implications for economic growth and social and environmental sustainability. Center for International Forestry Research (CIFOR) Working Paper 220. DOI: $10.17528 /$ cifor/006405

Porter, M. E., \& Kramer, M. K. (2011, JanuaryFebruary). Creating Shared Value, how to reinvent capitalism - and unleashawave ofinnovation. Harvard Business Review. Retrieved from https://www.communitylivingbc. ca/wp-content/uploads/2018/05/ Creating-Shared-Value.pdf

Pricewaterhouse Coopers (PwC). (2016). Industry 4.0: Building the digital enterprise. Retrieved from https:// www.pwc.com/gx/en/industries/ industries-4.0/landing-page/ industry-4.0-building-your-digital- enterprise-april-2016.pdf

Ridhwan, M. M., Wicaksono, G., Nurliana, L., Bary, P., Suryani, F. T., \& Satyanugroho, R. (2015). Analisis Daya Saing Dan Strategi Industri Nasional Di Era Masyarakat Ekonomi Asean Dan Perdagangan Bebas. Bank Indonesia Working Paper.

Rival, A., \& Levang, P. (2014). Palms of controversies: Oil palm and development challenges. Bogor, Indonesia: Center for International Forestry Research (CIFOR).

Savilaakso, S., Garcia, C., Garcia-Ulloa, J., Ghazoul, J., Groom, M., Guariguata, M.R., Laumonier, Y., Nasi, R., Petrokofsky, G., Snaddon, J., \& Zrust, M. (2014). Systematic review of effects on biodiversity from oil palm production. Center for International Forestry Research (CIFOR) Occasional Paper 116.

Schwab, K. (2016). The Fourth Industrial Revolution. Geneva, Switzerland: World Economic Forum.

Statistics Indonesia. (2017). Indonesian Palm Oil Statistics. Retrieved from https://www.bps.go.id/ publication/2018/11/13/ b73ff9a5dc9f8d694d74635f/ statistik-kelapa-sawit indonesia-2017.html

Tijaja, J., \& Faisal, M. (2014). Industrial Policy in Indonesia: A Global Value Chain Perspective. Asian Development Bank (ADB) Economics Working Paper 411.

United States Department of Agriculture 
(USDA). (2019). Indonesia

Biofuels Annual Report 2019.

Retrieved from https://apps. fas.usda.gov/ newgainapi/api/ report/ downloadreportbyfile name? filename $=$ Biofuels $\% 20$ A n n u a $1_{-} \mathrm{J}$ a k a r t a Indonesia 8-9-2019.pdf

van Noordwijk, M., Pacheco, P., Slingerland, M., Dewi, S., \& Khasanah, N. (2017). Palm oil expansion in tropical forest margins or sustainability of production? Focal issues of regulations and private standards. World Agroforestry Centre (ICRAF) Working Paper 274. DOI: http://dx.doi. org/10.5716/WP17366.PDF

World Trade Organization (WTO). (2019). Technological Innovation, Supply Chain Trade, And Workers in A Globalized World. Retrieved from https://www.wto.org/english/res_e/ publications_e/gvcd_report_19_e.htm

\section{Journal Articles (retrieved online, with} DOI)

Brandi, C. A. (2016). Sustainability Standards and Sustainable Development - Synergies and Trade-Offs of Transnational Governance. Sustainable Development, 25, 2534. DOI: $10.1002 / \mathrm{sd} .1639$

Carlson, M. K., Curran, M. L., Asner, G. P., Pittman, A. M., Trigg, S. N., \& Adeney, J. M. (2012). Carbon emissions from forest conversion by Kalimantan oil palm plantations. Science, 361, 11081111. DOI: https://doi.org/10.1038/ nclimate 1702

Curtis, P. G., Slay, C. M., Harris, N. L., Tyukavina, A., \&Matthew C. Hansen, M. V. (2018). Classifying drivers of global forest loss. Nature Climate Change, 3, 283-387. DOI: 10.1126/science.aau3445

De Marchi, V., Di Maria, E., \& Micelli, S. (2012). Environmental Strategies, Upgrading and Competitive Advantage in Global Value Chains. Business Strategy and the Environment, 22, 62-72. DOI: 10.1002/bse. 1738

Findlay, C., \& Pangestu, M. (2016). The Services Sector as a Driver of Change: Indonesia's Experience in the ASEAN Context. Bulletin of Indonesian Economic Studies, 52(1), 27-53. DOI: $10.1080 / 00074918.2016 .1161499$

Gereffi, G. (2013). Global value chains in a post-Washington Consensus world. Review of International Political Economy, 21(1), 9-37. DOI: $10.1080 / 09692290.2012 .756414$

Gereffi, G., Humphrey, J., \& Sturgeon, T. (2005). The Governance of Global Value Chains. Review of International Political Economy, 12(1), 78-104. DOI: 10.1080/09692290500049805

Jelsma, I., Schoneveld, G. C., Zoomers, A., \& van Westen, A. C. M. (2017) Unpacking Indonesia's independent oil palm smallholders: 
An actor-disaggregated approach to identifying environmental and social performance challenges. Land Use Policy, 69, 281-297. DOI: http://dx.doi.org/10.1016/j. landusepol.2017.08.012

Kaplinsky, R., \& Morris, M. (2015). Thinning and Thickening: Productive Sector Policies in The Era of Global Value Chains. European Journal of Development Research, 28, 625645. DOI: $10.1057 /$ ejdr.2015.29

Kimura, F., \& Chen, L. (2018). Value Chain Connectivity in Indonesia: the Evolution of Unbundlings. Bulletin of Indonesian Economic Studies, 54(2), 165-192. DOI: 10.1080/00074918.2018.1505412

Nadvi, K. (2008). Global standards, global governance and the organization of global value chains. Journal of Economic Geography, 8 (3), 323343. doi:10.1093/jeg/lbn003

Nesadurai, H. E. S. (2017). New Constellations of Social Power: States and Transnational Private Governance of Palm Oil Sustainability in Southeast Asia. Journal of Contemporary Asia, 48(2), 204229. DOI: https://doi.org/10.1080/ 00472336.2017 .1390145

Obidzinski, K., Andriani, R., Komarudin, H., \& Andrianto, A. (2012). Environmental and Social Impacts of Oil Palm Plantations and their Implications for Biofuel Production in Indonesia. Ecology and Society,17(1). DOI: http://dx.doi.
org/10.5751/ES-04775-170125

Pichler, M. (2015). Legal Dispossession: State Strategies and Selectivities in the Expansion of Indonesian Palm Oil and Agrofuel Production. Development and Chnage, $00(0)$, 1-26. DOI: $10.1111 /$ dech.12162

Tong, Y. S. (2017). Vertical Specialization or Linkage Development for Argocommodity value chain upgrading? The case of Malaysian Palm Oil. Land Use Policy, 68, 585-596. DOI: http://dx.doi.org/10.1016/j. landusepol.2017.08.020

Vijay, V., Pimm, S.L., Jenkins, C.N., \& Smith, S.J., (2016). The Impacts of Oil Palm on Recent Deforestation and Biodiversity Loss. PLoS ONE 11(7). DOI https://doi.org/10.1371/ journal.pone. 0159668

\section{Journal Articles (retrieved online, without DOI or page numbers)}

Bair, J. (2005). Global Capitalism and Commodity Chains: Looking Back, Going Forward. Competition \& Change, 9(2), 153-180.

Barrientos, S., Gereffi, G., \& Rossi, A. (2011). Economic and social upgrading in global production networks: A new paradigm for a changing world. International Labour Review, 150 (3-4), 319-340.

Porter, M. E. (2003). The Economic Performance of Regions. Regional Studies, 37(6-7), 549-578.

\section{$\underline{\text { Electronic source }}$}


Bisnis (2019, July 24). Sertifikasi Sawit Berkelanjutan (ISPO): Legalitas Lahan Jadi Batu Sandungan. Bisnis. Retrieved from https://ekonomi.bisnis.com/ $\mathrm{read} / 20190724 / 99 / 1128187 /$ sertifikasi-sawit-berkelanjutan-ispolegalitas-lahan-jadi-batu-sandungan

Borneonews. (2018, July 18). KUD Tani Subur Mampu Ubah Masalah Jadi Berkah. Borneonews. Retrieved from https://www.borneonews. co.id/berita/97834-kud-tani-suburmampu-ubah-masalah-jadi-berkah

European Sustainable Palm Oil (ESPO). (2019). Choosing Sustainable Palm Oil. Retrieved from https:// www.idhsustainabletrade. com/uploaded/2019/01/ EPSO_Vormgeving 2019 DEF_31012019.pdf

European Union. (2019). Commission Delegated Regulation. Retrieved from https://ec.europa.eu/info/law/ better-regulation/initiatives/ares2019-762855_en

Gereffi, G., \& Fernandez-Stark, K. (2016). Global value chain analysis: a primer (Ed. 2nd). The Duke Center on Globalization, Governance \& Competitiveness, Duke University.

Humphrey, J., \& Memedovic, O. (2006). Global value chains in the agrifood sector. United Nations Industrial Development Organization (UNIDO) Working Papers. Retrieved from https://www.unido. org/sites/default/files/2009-05/
Global_value_chains_in_the agrifood_sector_0.pdf

Indonesia Oil Palm Plantation Fund Management Agency (BPDPKS). (2018). Program Pembangunan Prasarana Perkebunan Kelapa Sawit. Retrieved from https:// www.bpdp.or.id/programpengembangan-sarana-danprasarana-perkebunan-kelapa-sawit

International Trade Centre (ITC). (2019). List of exporters for the selected product, Product: 1511 Palm oil and its fractions, whether or not refined (excluding chemically modified). Retrieved from https://www. trad e map.org/Country SelProduct_TS.aspx?nvpm $=1 \% 7 \mathrm{c}$ $\% 7 \mathrm{c} \% 7 \mathrm{c} \% 7 \mathrm{c} \% 7 \mathrm{c} 1511 \% 7 \mathrm{c} \% 7 \mathrm{c} \%$ $7 \mathrm{c} 4 \% 7 \mathrm{c} 1 \% 7 \mathrm{c} 1 \% 7 \mathrm{c} 2 \% 7 \mathrm{c} 2 \% 7 \mathrm{c} 1 \%$ $7 \mathrm{c} 2 \% 7 \mathrm{c} 1 \% 7 \mathrm{c} 1$

Katadata. (2019, September 21). Pengecekan Lapangan Beres, Satu Peta Sawit Nasional Segera Meluncur. Katadata. Retrieved from https://katadata. co.id/berita/2019/09/21/pengecekanlapangan-beres-satu-peta-sawitnasional-segera-meluncur

Kompas. (2019, June 28). Alokasi Dana Pungutan Ekspor CPO Belum Sejahterakan Petani. Kompas. Retrieved from https://kompas. $\mathrm{id} / \mathrm{baca} /$ ekonomi/2019/06/28/ progra m - bi od i e se 1 - haru s sejahterahkan-petani-kelapa-sawit/

Lee, Y. B. (2011). The Introduction of e-Government in Korea. Ministry of Strategy and Finance, Republic 
of Korea. Retrieved from http:// www.eksp.kr/common/donwload. jsp?fidval $=$ ARsV2SCd8AxKH4z tujscTQ\%3D\%3D

Ministry of Industry. (2015). Industry Facts and Figures. Retrieved from www. kemenperin.go.id/download

Ministry of Research, Technology and Higher Education. (2019). Katalis Merah Putih ITB Mulai Digunakan di Kilang Minyak Pertamina. Retrieved from https://ristekdikti.go.id /kabar/ katalis-merah-putih-itb-mulaidigunakan-di-kilang-minyakpertamina/\# 7 mHsF 3 EDyA 5 YeqyH.99

Plessis, A. D., \& Rautenbach, C. (2009). Legal Perspectives on the Role of Culture in Sustainable Development. Faculty of Law Colloquium on Good Governance and Sustainable Development. Retrieved from http://www.scielo.org.za/ scielo.php?script $=$ sci_arttext\& pid $=$ S1727-37812010000100002

Schwab, K. (2015, December 12). The Fourth Industrial Revolution. Foreign Affairs. Retrieved from https://www.foreignaffairs.com/ articles/2015-12-12/fourthindustrial-revolution

The Japan Times. (2019, January 14). World awash in sustainable palm oil, but consumers unwilling to pay premium for environmentally friendly supply. The Japan Times. Retrieved from https://www. japantimes.co.jp/news/2019/01/14/ world/world-awash-sustainablepalm-oil-consumers-unwillingpay-premium-environmentallyfriendly-supply/\#.XZsq8EYzZPY

World Wild Fund. (2019). Orang-utans. Retrieved from https://wwf.panda. org/knowledge_hub/endangered_ species/great_apes/orangutans/ 